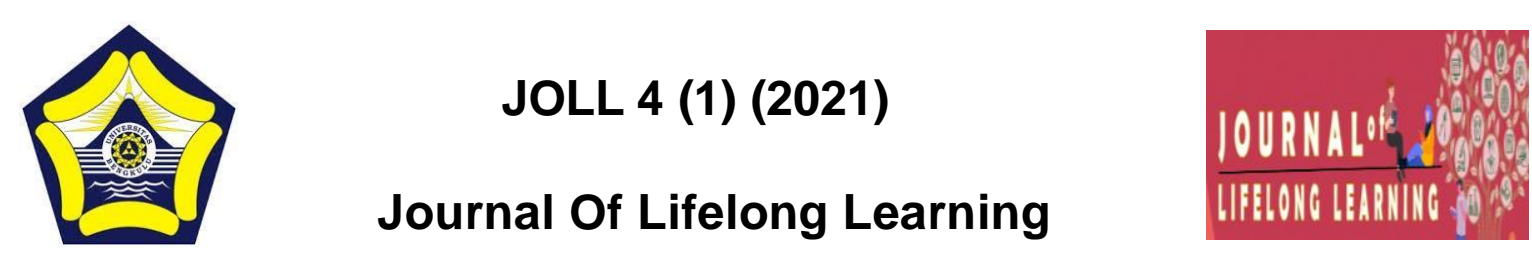

\title{
PEMBERDAYAAN MASYARAKAT MELALUI KELOMPOK TANI JERUK KALAMANSI
}

\author{
Hermelin Saras Putri ${ }^{1}$ Ririn Gusti ${ }^{2}$ \\ ${ }^{1}$ Hermelin Saras Putri, Universitas Bengkulu, Indonesia, \\ hermelinputri@gmail.com \\ ${ }^{2}$ Ririn Gusti, Universitas Bengkulu, Indonesia, riringusti@unib.ac.id
}

\begin{abstract}
This study aims to systematically obtain information related to community empowerment through kalamansi citrus farmer groups. The method used is the focus group discussion by getting the results that community empowerment through the kalamansi citrus farmer group was established in 2008, has 27 members, the natural lemongrass farmer group gets certificate of appreciation from the Governor of Bengkulu as an Independent Kalamansi Citrus Farm Farmer / Success in the Context of the 5oth Anniversary of Bengkulu Province, on 18 November 2018. As time goes by, Kalamansi oranges have produced many fruits, the empowerment of sustainable natural lemongrass farmer groups in Padang lemongrass village is one of a form of community empowerment. The community usually sells it in the form of fresh fruit to market traders in the city of Bengkulu. With the empowerment of this sustainable natural fresh farmer group, the community can use their land as a kalamansi orange plantation where the products they plant will be traded in the market or to Mr. Amti who needing the raw material for kalamansi syrup, the community can increase their family's economic income by planting kalamansi and oranges the community also conserves kalamsi citrus fruit in the city of Bengkulu. Keywords: Empowerment, farmer groups, kalamansi oranges.
\end{abstract}

Keywords: Empowerment, farmer groups, kalamansi oranges.

(C2021 DeptofNonformalEducationUNIB ISSN : 2715-9809

\footnotetext{
-Addresscorrespondence:

Jl.W.R.Supratman,KandangLimun,MuaraBangkaHulu,

KotaBengkulu,Bengkulu38371
} 


\section{PENDAHULUAN}

Pendidikan Masyarakat diartikan sebagai layanan pendidikan yang diperuntukan bagi masyarakat tanpa melihat perbedaan tingkat pendidikan, usia, status sosial, ekonomi, agama, suku dan kondisi mental fisiknya, yang mempunyai keinginan untuk menambah dan atau meningkatkan kompetensi untuk meningkatkan kesejahteraan hidupnya

Pendidikan berbasis masyarakat menurut Sihombing (2001) merupakan pendidikan yang dirancang, dilaksanakan, dinilai dan dikembangkan oleh masyarakat yang mengarah pada usaha menjawab tantangan dan peluang yang ada di lingkungan masyarakat tertentu dengan berorientasi pada masa depan. Dengan kata lain, pendidikan berbasis masyarakat adalah konsep pendidikan "dari masyarakat, oleh masyarakat dan untuk masyarakat”. Dengan ini Sihombing menegaskan bahwa yang menjadi acuan dalam memahami pendidikan berbasis masyarakat adalah pendidikan luar sekolah, karena pendidikan luar sekolah itu bertumpu pada masyarakat, bukan pada pemerintah. Ia dapat mengambil bentuk Pusat Kegiatan Belajar-Mengajar (PKBM) yang tumbuh subur dan masyarakat berlomba-lomba untuk mendirikannaya. Di seluruh Indonesia hingga tahun 2000-an terdapat sekitar 760 PKBM. Hal senada juga diungkapkan oleh Supriadi (2000) yang mengkaji fenomena TKA/TPA yang muncul di Indonesia semenjak 1980-an. Ia menyebutkan bahwa pendidikan berbasis masyarakat merupakan proses pendidikan yang lahir dari kebutuhan masyarakat. Oleh karenanya tak perlu dikekang oleh aturanaturan formal dari pemerinta, fenomena TKA/TPA kiranya dapat dijadikan model alternasi bagi pengembangan pendidikan berbasis masyarakat, terutama dari segi keterlepasannya dari birokrasi pemerintah. Ia senantiasa terwujud sebagai bukti dari akomodasi kehendak masyarakat untuk membelajarkan anak-anaknya.

Pemberdayaan menurut arti secara bahasa adalah proses, cara, perbuatan membuat berdaya, yaitu kemampuan untuk melakukan sesuatu atau kemampuan bertindak yang berupa akal, ikhtiar atau upaya (Depdiknas, 2003). Masyarakat adalah kesatuan hidup manusia yang berinteraksi menurut suatu sistem adat istiadat tertentu yang bersifat kontinyu, dan yang terikat oleh suatu rasa identitas bersama (Koentjaraningrat, 2009). Dalam beberapa kajian mengenai pembangunan komunitas, pemberdayaan masyarakat sering dimaknai sebagai upaya untuk memberikan kekuasaan agar suara mereka didengar guna 
memberikan kontribusi kepada perencanaan dan keputusan yang mempengaruhi komunitasnya (Foy, 1994). Pemberdayaan adalah proses transisi dari keadaan ketidakberdayaan ke keadaan kontrol relatif atas kehidupan seseorang, takdir, dan lingkungan (sadan,1997).

Menurut Chamber, pemberdayaan masyarakat adalah sebuah konsep pembangunan ekonomi yang merangkum nilai-nilai social. Konsep ini mencerminkan paradigma baru pembangunan yang bersifat "people centered", participatory, dan suistanable. Konsep pemberdayaan lebih luas dari sekedar upaya untuk memenuhi kebutuhan dasar atau sekedar mekanisme untuk mencegah proses pemiskinan lebih lanjut (safety net).

$$
\text { Menurut Mubarak }
$$

pemberdayaan masyarakat dapat diartikan sebagai upaya untuk memulihkan atau meningkatkan kemampuan suatu komunitas untuk mampu berbuat sesuai dengan harkat dan martabat mereka dalam melaksanakan hak-hak dan tanggung jawabnya selaku anggota masyarakat.

Dari penyataan diatas maka dapat disimpulkan pemberdyaan masyarakat yaitu kegiatan yang biasa menumbuhkan rasa ingin memciptakan sesuatu potensi yang ada didalam lingkungan tersebut dan berinisiatif untuk pemperbaiki stuasi dan kondisi yang ada dilingkungannya dengan cara berpartisifasi antar individu.

Kampung kalamansi padang serai yang terletak di Kecamatan kampung melayu kelurahan padang serai yang memiliki potensi lahan pertanian untuk menanam jeruk kalansi, di desa tersebut memiliki lahan yang bagus dan luas untuk di jadikan lahan peranian dan masyarakat membuat kelompok tani yang bernama serai alam lestari yang di ketuai oleh bapak Amti Chaniago sejak tahun 2008 sampai saat ini, masyarakat desa yang mempunyai lahan untuk menanam jeruk kalamansi sendiri sudah mendapatkan hasil buahnya yang sudah di petik biasaanya dijualkan ke berbagai pasar yang adi di kota Bengkulu dan juga di beli oleh bapak Amti untuk membuat o3lahan sirup kalamansi. Dari data yang dijabakan diatas, maka peneliti tertarik untuk melakukan penelitian tentang "pemberdayaan masyarakat melalui kelompok tani jeruk kalamansi”.

\section{METODE}

a. Metode penelitian

\section{Pengertia FGD}

FGD adalah salah satu teknik pengumpulan data kualitatif yang banyak digunakan, khususnya oleh pembuat keputusan atau peneliti, 
karena relatif cepat selesai dan lebih murah. Teknik FGD mempermudah pengambil keputusan atau peneliti dalam memahami sikap, keyakinan, ekspresi dan istilah yang biasa digunakan oleh peserta mengenai topik yang dibicarakan, sehingga sangat berguna untuk mengerti alasan-alasan yang tidak terungkap dibalik respons peserta

a. Diskusi - bukan wawancara atau obrolan

b. Kelompok - bukan individual

c. Terfokus - bukan bebas

\section{Tujuan FGD}

Tujuan FGD adalah untuk mengeksplorasi masalah yang spesifik, yang berkaitan dengan topik yang dibahas. Teknik ini digunakan dengan tujuan untuk menghindari pemaknaan yang salah dari peneliti terhadap masalah yang diteliti. FGD digunakan untuk menarik kesimpulan terhadap makna-makna intersubjektif yang sulit diberi makna sendiri oleh peneliti karena dihalangi oleh dorongan subjektivitas peneliti (Kresno S. dkk., 1999).
Peserta memiliki kesamaan ciri, tidak saling mengenal Jumlah peserta dalam kelompok cukup 7-10 orang, namun dapat diperbanyak hingga 12 orang, sehingga memungkinkan setiap individu untuk mendapat kesempatan mengeluarkan pendapatnya serta cukup memperoleh pandangan anggota kelompok yang bervariasi (Krueger, 1988). Jumlah peserta yang lebih besar, sebenarnya juga bisa memberi keuntungan lain, yaitu memperluas sudut pandang dan pengalaman peserta yang mungkin muncul. Namun walaupun jumlah peserta tidak banyak dan waktu untuk mengemukakan pendapat tidak dibatasi, peserta mempunyai batasan waktu tertentu dalam berbicara karena fokus perhatian tidak hanya pada satu responden melainkan seluruh peserta. Inilah yang membedakan teknik pengumpulan data

b. Tempat penelitian

Penelitian ini dilakukan $\mathrm{Jl}$. Suka Maju, Kelurahan Padang Serai Kecamatan Kampung Melayu Kota Bengkulu.

\section{Karakteristik FGD}




\section{HASIL PEMBAHASAN}

Penelitin ini dilaksanakan di kediaman ketua kelompok tani Serai Alam Lestari Jl. Suka maju, kelurahan padang serai kecamatan kampong melayu kota Bengkulu.

\section{A. Persiapan dan Desain Rancangan FGD}

1. Membentuk Tim FGD umumnya mencakup:

- Moderator yakni Amti Chaniago

- Pencatat Proses/Notulen yakni Maryadi

- Penyedia Logistik, yaitu seluruh anggota kelompok tani serai alam lestari.

- Dokumentasi, yaitu Boiman

2. Memilih dan mengatur tempat di Jl. Suka Maju, Kelurahan Padang Serai Kecamatan Kampung Melayu Kota Bengkulu.

3. Jumlah perserta 10 orang biar FGD bisa fokus

\section{B. Menyusun Pertanyaan FGD}

Penyusunan pertanyaanpertanyaan/Guideline pada FGD dilakukan dengan melihat beberapa hal berikut ini:

- Tujuan penelitian FGD

- Tujuan diadakannya FGD
- Memahami jenis informasi seperti apa yang ingin didapatkan dari FGD

- Menyusun dari pertanyaan umum ke pertanyaan khusus.

\section{Pelaksanaan FGD}

a. Menjelaskan maksud dan tujuan FGD.

Moderator menjelaskan secara detail maksud dan tujuan FGD hanya untuk kepentingan penelitian dan data responden akan dijaga kerahasiannya (tidak akan dipublikasikan keluar)

b. Menjelaskan topik/isu pokok diskusi

c. Menjelaskan tata cara pelaksanaan dalam FGD

d. Menciptakan suasana kondusif.

e. Mengelola dinamika kelompok.

Dari hasil Metode FGD Mendapatkan informasi dari ketua kelompok budidaya jeruk kalamansi serai alam lestari kelurahan padang serai kota Bengkulu kepada bapak Amti Chaniago selaku ketua kelompok tani dan anggota sebanyak 27 orang. Beliau megatakan bahwa mulai merintis menanam jeruk kalamansi di tahun 2008 dengan mengajak anggota kelompok tani untuk menanam jeruk kalamansi karena di daerah mereka terdapat tanah yang subur dan lahan yang kosong, setiap masyarakat yang mempunyai lahan yang luas diajak untuk 
menanam jeruk kalamansi supaya bisa menghasilkan pemasukan masyarakat tersebut dan kelompok tani serai alam lestari mendapatkan piagam penghargaan dari Guburnur Bengkulu Sebagai Petani Kebun Jeruk Kalamansi Mandiri/Berhasil Dalam Rangka HUT Emas Provinsi Bengkulu Ke50, Pada 18 November 2018. Seiring berjalannya waktu jeruk kalamansi menghasilkan banyak buah terus menerus dan pasar tidak bisa menampung lagi karena jeruk kalamansi berbuah dengan lebat, bapak Amti sendiri berinisiatif untuk megikuti pelatihan pembuatan olahan sirup kalamansi segar asri pada tahun 2011 dan mulai membuat olahan jeruk kalamansi menjadi sirup kalamansi dengan bahan bakunya membeli kepada masyarakat yang mengikutu kelompok tani dan jika pak Amti merasa cukup dengan buah untuk dijadikan sirup, masyarakat biasanya menjualnya dengan bentuk buah segar kepedagang pasar yang ada di kota Bengkulu dengan adanya pemberdayaan kelompok tani segar alam lestari ini masyarakat dapat memanfaatkan lahan tanah milik mereka sebagai kebun jeruk kalamansi yang dimana hasil dari yang mereka tanam akan diperjual belikan dipasar ataupun kepada bapak Amti yang membutuhkan bahan baku untuk sirup kalamansi, masyarakat dapat menambah penghasilan ekonomi keluarga dengan menanam jeruk kalamansi dan masyarakat juga melestarikan buah jeruk kalamsi di kota Bengkulu.

Menurut Soerjono Soekanto, "Masyakarat adalah orang-orang yang hidup bersama yang menghasilkan suatu kebudayaan"(1990:187). Dengan demikian, tak ada masyarakat yang tidak mempunyai kebudayaan dan sebaliknya tak ada kebudayaan tanpa masyarakat sebagai wadah dan pendukungnya. Menurut M. Cholil Mansyur masyarakat di defenisikan sebagai "golongan besar atau kecil terdiri atas beberapa manusia dengan atau karena sendirinya bertalian secara golongan, masyarakat itu sendiri merupakan suatu kesatuan yang selalu berubah yang hidup karena proses mayarakat seperti tersebut diatas yang menyebabkan perubahan" (1989:87), sehingga dapat disimpulkan bahwa masyarakat merupakan orang-orang yang hidup bersama atau golongan besar atau kecil dari beberapa manusia yang melakukan interaksi dan saling bergaul dalam lingkungan sosial yang berupa satu kesatuan, hidup secara mandiri, bebas dan menghasilkan suatu kebudayaan.

Ekonomi adalah ilmu tentang perilaku dan tindakan manusia untuk memenuhi kebutuhan hidupnya yang banyak, 
bervariasi dan berkembang dengan sumber daya yang ada melalui perubahan-perubahan kegiatan produksi, konsumsi dan distribusi. Suherman Rosyidi menjelaskan : "Bahwa istilah ekonomi itu berasal dari bahasa yunani, yaitu Oikonomia. Kata tersebut merupakan turunan dari dua kata, yakni oikos dan nomos. Oikos berarti rumah tangga, sedangkan nomos berarti mengatur. Jadi arti asli oikonomia adalah mengatur rumah tangga" (2004:20).

Ekonomi merupakan kata serapan dari bahasa Inggris, yaitu economy sementara kata ekonomi itu sendiri berasal dari bahasa Yunani, yaitu oikonomike yang berarti pengelolaan rumah tangga. Adapun yang dimaksud dengan ekonomi sebagai pengelolaan rumah tangga adalah surat usaha dalam pembuatan keputusan dan pelaksanaannya dengan berhubungan dengan pengalokasian sumber daya rumah tangga yang terbatas diantara berbagai anggotanya, dengan mempertimbangkan kemampuan, usaha keinginan masing-masing. Oleh karena itu, suatu rumah tangga selalu dihadapkan pada banyak keputusan dan pelaksanaannya. Tidak berbeda halnya dengan rumah tangga, masyarakat juga selalu dihadapkan pada banyak keputusan dan pelaksanaanya

Untuk mewujudkan peningkatan perekonomian berdasarkan karakteristik potensi, geografis dan kebutuhan daerah, maka strategi kebijakan yang dilakukan adalah sebagai berikut:

1. Menigkatkan aksesibilitas untuk memperlancar aliran investasi dan produksi serta

menigkatkan keterkaitan ekonomi antar daerah yang saling mendukung.

2. Mendorong pemanfaatan potensi sumber daya alam yang belum tergali di daerah tirtinggal dan menciptakan perkembangan kawasan-kawasan potensi ekonomi baru.

3. Menigkatkan kelangsungan kegiatan usaha yang sudah ada di sentrasentraproduksi di daerah yang relatif maju sebagai andalan pertumbuhan ekonomi dan mengembangkannya dalam kerangka prekonomian wilayah berdasarkan kesamaan karakteristik potensi geografis dan kebutuhan daerah

4. Meningkatkan kemampuan pemerintah daerah dalam mengembangkan daya tarik investasi berdasarkan keunggulan komperatif dan kompetitif masing-masing daerah sesuai dengan potensi sumberdaya alam, sumber daya manusia, dan lokasi geografis. 


\section{KESIMPULAN}

Kelompok tani serai alam lestari terletak di Jl. Suka Maju, Kelurahan Padang Serai Kecamatan Kampung Melayu Kota Bengkulu. Kelompok tani jeruk kalamansi berdiri pada tahun 2008, memiliki 27 orang angota, pemberdayaan kelompok tani serai alam lestari pada kelurahan padang serai ini adalah salah satu pembentuk pemberdayaan masyarakat, kelompok tani serai alam lestari mendapatkan piagam penghargaan dari Guburnur Bengkulu Sebagai Petani Kebun Jeruk Kalamansi Mandiri/Berhasil Dalam Rangka HUT Emas Provinsi Bengkulu Ke50, Pada 18 November 2018. Dengan adanya pemberdayaan kelompok tani segar alam lestari ini masyarakat dapat memanfaatkan lahan tanah milik mereka sebagai kebun jeruk kalamansi yang dimana hasil dari yang mereka tanam akan diperjual belikan dipasar ataupun kepada bapak Amti yang membutuhkan bahan baku untuk sirup kalamansi, masyarakat dapat menambah penghasilan ekonomi keluarga dengan menanam jeruk kalamansi dan masyarakat juga melestarikan buah jeruk kalamsi di kota Bengkulu.

\section{DAFTAR PUSTAKA}

Almaidah, S. (2017). Analisis Efektivitas Kinerja Pusat Kegiatan Belajar Masyarakat (PKBM) Dalam Menyelenggarakan Program
Pendidikan Berbasis

Masyarakat. Media Ekonomi dan Manajemen, 32(2).

Muhtar, Fathurrahman, and Siti Hajaroh. "Pemberdayaan pemuda desa melalui budi daya jamur tiram di Desa Lembah Sempage Narmada Lombok Barat." Transformasi: Jurnal Pengabdian Masyarakat 12.2 (2016): 157-167. 20840-ID-teknik-focusgroup-discussion-dalam-penelitiankualitatif.pdf

Suharto, T. (2005). Konsep dasar pendidikan berbasis masyarakat. Jurnal Cakrawala Pendidikan, (3).

http://repository.uinsu.ac.id/8602/1/Skripsi.p df

$\underline{\text { http://jurnal.um- }}$ tapsel.ac.id/index.php/muqoddimah/ article/view/279

https://safiraspd.blogspot.com/2016/10/peng ertian-pendidikan-masyarakatdan.html\#: :text=Pendidikan\%20Ma syarakat $\% 20$ diartikan $\% 20$ sebagai $\% 2$ 0layanan,meningkatkan\%20kompete nsi\%20untuk\%20meningkatkan\%20 kesejahteraan 